\title{
Primary Systemic Amyloidosis - an Unusual Cause of Diarrhea
}

\author{
CARMEN PLAISANUㄴ, VLAD DUMITRU BALEANU2*, DRAGOS VIRGIL DAVITOIU³, CORINA MEIANU4, MIRCEA DICULESCU4, \\ COSMIN ALEXANDRU CIORA ${ }^{4}$ \\ ${ }^{1}$ Gastroenterology and Hepatology, Fundeni Clinical Institute , 258 Fundeni Road Bucharest, Romania \\ 'University of Medicine and Pharmacy of Craiova, Surgery Department, Clinical Emergency Hospital Sf. Pantelimon Bucharest, \\ 340-342 Pantelimon Road, 021659, Bucharest, Romania \\ ${ }^{3}$ University of Medicine and Pharmacy of Bucharest, Surgery Department, Clinical Emergency Hospital Sf. Pantelimon Bucharest, \\ 340-342 Pantelimon Road, 021659, Bucharest, Romania \\ ${ }^{4}$ Carol Davila University of Medicine and Pharmacy, Discipline of Gastroenterology and Hepatology, 8 Eroii Revolutiei Blvd., \\ 050474, Bucharest, Romania
}

\begin{abstract}
The amyloidosis is a group of rare diseases caused by extracellular deposition of amyloid. It may affect multiple organs with protean manifestations, thus often causing delayed or incorrect diagnoses. We report a case of gastrointestinal involvement in primary systemic amyloidosis (PSA) in a patient complaining of diarrhea and weight loss. The diagnosis was confirmed by endoscopic biopsies of upper digestive tractand by multidisciplinary evaluation for systemic involvement.
\end{abstract}

Keywords: Amyloidosis, Chronic diarrhea, Red Congo stain, Immunohistochemistry

In patients with amyloidosis, recent data suggest an improved prognosis, with the median survival time increasing from six months to 18 months. Therapeutic success depends on an accurate and early diagnosis because prognosis worsens with the number and extent of organs involved. Amyloidosis mainly affects the heart, the kidneys and, commonly, the peripheral and autonomous nervous systems. However, gastrointestinal involvement, with symptoms such as chronic diarrhea, obstipation and steatorrhea, may also occur. The case described in the present article involved nonspecific but typical clinical manifestations of systemic amyloidosis and the appropriate diagnostic strategy is discussed.

\section{Experimental part}

A 78-year-old male with chronic kidney disease, recurrent pleural and pericardial effusion, chronic anemia, chronic cholestasis presented for diarrhea up to 4-5 stools/ day, related to meals, early satiety and weightloss, physical asthenia, peripheral paresthesiae, eye dryness, symptoms ongoing for the last 6 months.

\section{Clinical examination}

Atphysical examination the patient had a normal weight with a BMI of $20 \mathrm{~kg} / \mathrm{m}^{2}$, cutaneo-mucosal pallor, peripheral oedema, orthostatic hypotension, reduced right lower thoracic basis normal breath sounds, hepatomegaly with inferior liver margin at 4-5 cm under costal border.

\section{Laboratory findings}

Significant biochemical changes in blood test showed macrocytic anemie Hb 9.4 g/dL (11.6-16.8), MCV $102 \mathrm{fL}$ (80-100), albumin $2.8 \mathrm{~g} / \mathrm{dL}$ (3.5-5), creatinine $2.94 \mathrm{mg} / \mathrm{dL}$ (0.5-1.3), alkaline phosphatise $192 \mathrm{U} / \mathrm{L}$ (40-130), gamma glutamyl transferase $112 \mathrm{U} / \mathrm{L}$ (10-87), vitamin B12 $90 \mathrm{pg} /$ $\mathrm{mL}(180-211)$, CRP $58 \mathrm{mg} / \mathrm{L}(<3)$. Stool tests were negative for Salmonella, Shigella, Yersinia and Clostrium difficile.

\section{Paraclinical examination}

Abdominal ultrasound showed an enlarged homogenous liver with a craniocaudal diameter of $210 \mathrm{~mm}$. Upper digestive tract endoscopy revealed a pale stomach mucosa with prominent submucossal vessels and a jejunal mucosa with smooth tubular surface and flattened villi (Fig. $1)$.

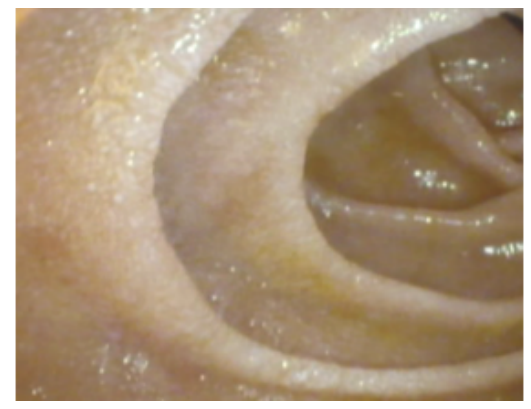

Fig. 1. Endoscopic aspect of jejunum. Flattened villi and smooth tubular surface

\section{Histopathology examination}

At thr histological examination of stomach and jejunum showed mucosa presenting vessels with thickened walls by deposition of positive Congo Red material, with green birefringence in the polarized light examination. Immunohistochemistry revealed vascular wall depositis positive for amyloid $\mathrm{A}$ with an intense reaction for lightweight kappa chains (Fig. 2, Fig. 3).

Further, the patient underwent investigations for the assessment of the systemic involvement. Schimmer test diagnosed Sicca syndrome with Schimmer test $=1 \mathrm{~mm}$ lacrimal, electromyography was positive for moderate axonal sensorimotor polyneuropathy, cardiac ultraspund showed left ventricle wall hypertrophy with an interventricular septum of $14 \mathrm{~mm}$ and the electrocardiogram showed low QRS voltage, urinary test revealed a proteinuria of $0.24 \mathrm{~g} / 24 \mathrm{~h}$. Bone marrow aspirate showed normal cellularity, small interstitial and perivascular lymphocytic infiltrate and Congo red coloration negative, immunohistochemistry for CD 138 positive plasmocytes kappa/lambda was negative. The patient died soon after the initiation of dexamethasone due to complications caused by Clostridium difficile colitis and infectious pneumonia. 

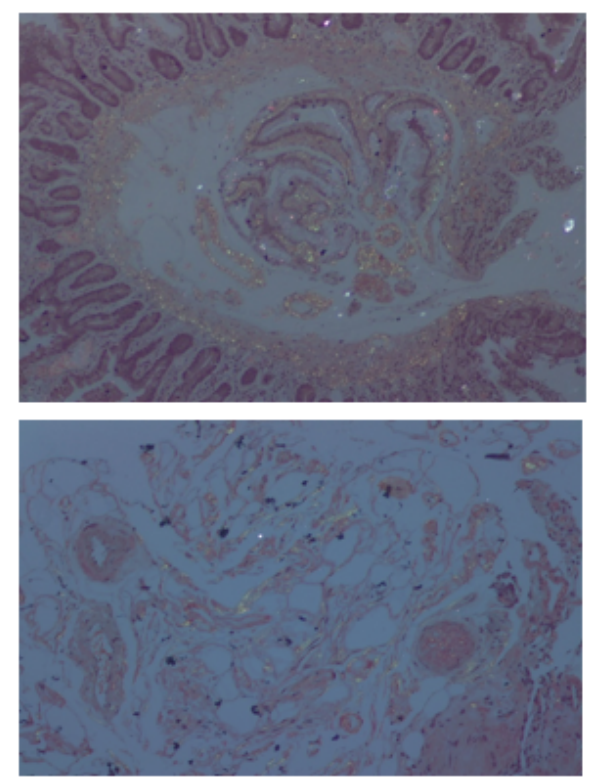

Fig 2., Fig 3. Jejunal biopsy with Congo Red stain showing green birefringence under polarized light compatible with amyloid deposits, 200x

\section{Results and discussions}

Immunoglobuline light chain amylodosis ( $A L)$ is the most common type of systemic amyloidosis with an incidence estimated yearly at nine cases /million in western countries [1]. AL amyloidosis is a plasma cell dyscrasia characterized by extracellular accumulation of beta-pleated fibrillar depositis of monocolonal light chain immunoglobulin.

Kidney involvement is the most common characterized by nephrotic syndrome [2]. At diagnosis our patient had no nephrotic range proteinuria. Heart involvement is represented by deposits of amyloid in the cardiac walls causing restrictive cardiopathy [3]. Peripheral nerve involvement includes sensorimotor peripheral and autonomic neuropathy that can manifest as gastroparesis, diarrhea or constipation or postural hypotension [4]. Hepatic involvement although common, clinical manifestations are mild. It is mostly characterized by hepatomegaly and abnormal liver function tests. Gastrointestinal involvement includes impaired intestinal transit, weight loss, dyspepsia, and gastrointestinal bleeding [5-9].

In our patient chronic diarrhea can be caused by mixed mechanisms: infiltrative by amyloid deposits in the intestine and neurological by peripheral neuropathy. Also intestine and gastric infiltration can explain hypoalbuminemia with no renal involvement and $B 12$ deficit.

The diagnosis of $A L$ amyloidosis is based by the detection of extracellular Congo red deposits by light chain microscopic examination that display apple green birefringence under polarized light. It is advisable that the biopsies to be obtained non-invasively from abdominal fat or minor salivary glands. If negative, it is to be considered biopsy from a clinically affected organ [2]. Once the tissue amyloid deposit was confirmed plasma cell dyscrasia must be confirmed by the predominace of gamma and kappa-producing plasma cells in the bone marrow aspirate although definitive results are obtained in less than $60 \%$ cases [10-13]. Treatment includes oral merphalan and prednisone or dexamethasone [14].

\section{Conclusions}

Gastrointestinal amyloidosis should be considered in patients with chronic diarrhea, especially if it is combined with weight loss, edema, anemia, low voltage in the ECG or other possible signs of a systemic amyloidosis and if more common diseases have been excluded. Besides chronic diarrhea, stasis symptoms such as vomiting, nausea, gastrointestinal reflux, early satiety can also occur in systemic amyloidosis. Early and accurate diagnosis and a promptinitiation of treatmentare critical for the prognosis of light-chain amyloidosis. We hope that this report will help our peers keep vigilant of underlying diseases when similar clinical scenario occurs in order to make a prompt diagnosis and effective treatment.

\section{References}

1. GERTZ MA. Immunoglobulin light chain amyloidosis: 2018 Update on diagnosis, prognosis, and treatment. Am J Hematol. 2018;

2. JACCARD A, DESPORT E, MOHTY D, BRIDOUX F. AMYLOSE AL. Rev. Med. Interne. 2015.

3. SELVANAYAGAM JB, HAWKINS PN, PAUL B, MYERSON SG, NEUBAUER

S. Evaluation and Management of the Cardiac Amyloidosis. J. Am.

Coll. Cardiol. 2007.

4. SHIN SC, ROBINSON-PAPP J . Amyloid neuropathies. Mt Sinai J Med. 2012;

5. ROWE K, PANKOW J, NEHME F, SALYERS W. Gastrointestinal Amyloidosis: Review of the Literature. Cureus. 2017;

6. NEDELCUTA, R.M., CALIN, G., BALEANU, V.D., DAVITOIU, D.V., VOICULESCU, D.I., MIREA, C.S., TENEA COJAN, T.S. , SOCEA, B., ALEXANDRU, D.O., CLENCIU, D., GHEORMAN, V., UDRISTOIU, I., CALBOREAN, V., CIORA, C.A. Anorexia, a First Sign of Diagnosis in Severe Pediatric Disorders. Rev. Chim. (Bucharest), 70, no. 5, 2019, p. 1698-1702.

7. STANESCU, G.L., NEDELCUTA, R.M., DOP, D., DIACONU, R., CALIN, G., NICULESCU, E.C., GHEONEA, C., STANESCU, R., ANGHELINA, L., STANESCU, M.R. Brain abscess of unknown etiology in a 2-year-old child: a case report. Rom J Morphol Embryol 2015, 56(3). p. 12011204.

8. CLENCIU, D., TENEA COJAN, T.S., DIJ MARESCU, A.L., ENE , C.G., DAVITOIU, D.V., BALEANU, V.D., CIORA, C.A., SOCEA, B., VOICULESCU, D.I., NEDELCUTA R.M., CALBOREAN, V., GHEORMAN, V., VLADU,I.M. Diabetic Retinopathy in Relation with eGDR Value in Patients with Type 1 Diabetes Mellitus. Rev.Chim. (Bucharest),70, no.4, 2019, p. 1434-1438.

9. NEDELCUTA, R., BALEANU, V.D., CIORA, C., CALIN, G., STANESCU, M.R. , DAVITOIU, D.V., TENEA-COJAN, T.S., SOCEA, B., VOICULESCU, D.I., ALEXANDRU, D.O., STANESCU, R. Possible Retard in the Language Development to the Children Born through IVF (In Vitro Fertilisation). Rev. Chim. (Bucharest), 70, no.5, 2019, p. 1859-1862.

10. GHEORMAN, V., DINESCU, V.C., CRICIOTOIU, O., STANCA, D., CALBOREAN, V., MITA, A., MISCOCI, A., DAVITOIU, D.V., BALEANU, V.D., NEDELCUTA, R.M., DINESCU, S.N., DIJ MARESCU, A.L., VOICULESCU, D.I., UDRISTOIU, I. Clinical and Biochemical Changes Induced by Alcohol at the Patients with Mental Illness. Rev. Chim. (Bucharest), 70, no. 4, 2019, p. 1406-1410.

11. NEDELCUTA, R., POPESCU, M., CALIN, G. Digestive Manifestations in Wilms' Tumor. NEUROGASTRO 2017 - MEETING OF THE ROMANIAN SOCIETY OF NEUROGASTROENTEROLOGY WITH ROME IV REGIONAL CENTRAL EAST EUROPEAN MEETING. 2017, p. 200-204.

12. SANCHORAWALA V. Light-chain (AL) amyloidosis: diagnosis and treatment. Clin. J. Am. Soc. Nephrol. 2006.

13. GILLMORE JD, WECHALEKAR A, BIRD J, CAVENAGH J, HAW KINS $S$, KAZMI M, et al. Guidelines on the diagnosis and investigation of $A L$ amyloidosis. Br J Haematol. 2015;

14. WECHALEKAR AD, GILLMORE JD, HAWKINS PN. Systemic amyloidosis. Lancet. 2016.

Manuscript received: 28.06 .2019 